\title{
Purinergic Signalling: Pathophysiology and Therapeutic Potential
}

\author{
Geoffrey Burnstock ${ }^{1,2}$ \\ ${ }^{1}$ Autonomic Neuroscience Centre, University College Medical School, London, UK \\ ${ }^{2}$ Department of Pharmacology, The University of Melbourne, Melbourne, Australia
}

(Received for publication on April 26, 2013)

(Revised for publication on May 31, 2013)

(Accepted for publication on June 28, 2013)

\begin{abstract}
The article begins with a review of the main conceptual steps involved in the development of our understanding of purinergic signalling, including non-adrenergic, non-cholinergic (NANC) neurotransmission; identification of ATP as a NANC transmitter; purinergic cotransmission; recognition of two families of purinoceptors [P1 (adenosine) and P2 (ATP/ADP)]; and, later, cloning and characterisation of P1 (G protein-coupled), P2X (ion channel) and P2Y (G protein-coupled) receptor subtypes. Further studies have established the involvement of ATP in synaptic neurotransmission in both ganglia and in the central nervous system; long-term (trophic) purinergic signalling in cell proliferation, differentiation and death occurring in development and regeneration; and short-term purinergic signalling in neurotransmission, neuromodulation and secretion. ATP is released from most cell types in response to gentle mechanical stimulation and is rapidly degraded to adenosine by ecto-nucleotidases. This review then focuses on the pathophysiology of purinergic signalling in a wide variety of systems, including urinogenital, cardiovascular, airway, musculoskeletal and gastrointestinal. Consideration is also given to the involvement of purinoceptors in pain, cancer and diseases of the central nervous system. Purinergic therapeutic approaches for the treatment of some of these diseases are discussed. (doi: 10.2302/kjm.2013-0003-RE; Keio J Med 62 (3) : 63-73, September 2013)
\end{abstract}

Keywords: ATP, bladder disorders, hypertension, pain, CNS diseases

\section{Introduction}

The emphasis in this article is on the growing interest in the pathophysiology and therapeutic potential of purinergic signalling. ${ }^{1-8}$ However, it begins with a review of the discovery and main conceptual steps that have contributed to our current understanding of purinergic signalling.

\section{Basic Science - Conceptual Steps}

\section{Non-adrenergic, non-cholinergic neurotransmission}

The sucrose-gap technique for recording correlated mechanical and electrical activity of smooth muscle was de- scribed $^{9}$ and applied to a guinea-pig taenia coli innervated smooth muscle preparation. ${ }^{10,11}$ Experiments were carried out at Melbourne University in which neurotransmission mediated by the classical autonomic neurotransmitters acetylcholine (ACh) and noradrenaline (NA) were blocked by atropine and bretylium. We were expecting to see direct stimulation of the smooth muscle resulting in depolarisation and contraction. However, to our surprise and excitement, the response was hyperpolarisation to single pulses and relaxation. Tetrodotoxin, which was known to block nerve conduction but not affect smooth muscle activity, completely blocked the hyperpolarisations (Fig. 1), showing that they were inhibitory junction potentials in response to non-adrenergic, noncholinergic (NANC) neurotransmission. ${ }^{12}$ It was later shown that the response to NANC nerve stimulation was mediated

Presented at the 1852nd Meeting of The Keio Medical Society in Tokyo, March 25, 2013.

Reprint requests to: Geoffrey Burnstock, PhD, Autonomic Neuroscience Centre, University College Medical School, Rowland Hill Street, London NW3 2PF, UK, E-mail: g.burnstock@ucl.ac.uk

Copyright (C) 2013 by The Keio Journal of Medicine 


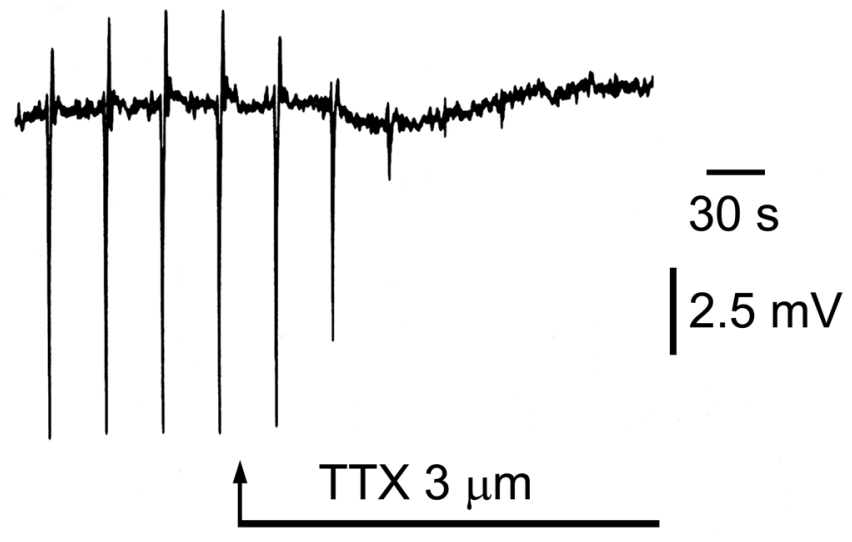

Fig. 1 Sucrose-gap recording of membrane potential changes in smooth muscle of guinea-pig taenia coli in the presence of atropine $(0.3 \mu \mathrm{M})$ and guanethidine $(4 \mu \mathrm{M})$. Transmural field stimulation $(0.5 \mathrm{~ms}, 0.033 \mathrm{~Hz}, 8 \mathrm{~V})$ evoked transient hyperpolarisations, which were followed by rebound depolarizations. Tetrodotoxin (TTX, $3 \mu \mathrm{M}$ ) added to the superfusing Kreb's solution (applied at arrow) rapidly abolished the response to transmural field stimulation, establishing these as inhibitory junction potentials in response to non-adrenergic, non-cholinergic neurotransmission. (Reproduced from Burnstock ${ }^{98}$ with permission of Blackwell Publishing.)

by intrinsic inhibitory enteric neurones that were controlled by vagal and sacral parasympathetic nerves. ${ }^{13}$

\section{Purinergic neurotransmission}

We tried to identify the transmitter involved in NANC inhibitory neurotransmission in the gut and NANC excitatory neurotransmission in the urinary bladder by seeing if neuropeptides, monoamines or amino acids satisfied the criteria proposed by Eccles, but we were not successful. However, after reading two papers, one by Drury and Szent-Györgyi ${ }^{14}$ that described extracellular actions of purines on the heart and blood vessels and a later paper by Pamela Holton ${ }^{15}$ that showed release of ATP during antidromic stimulation of sensory nerves, in 1970, together with David Satchell, we showed that ATP satisfied the criteria for NANC neurotransmission in both gut and bladder. ${ }^{16,17}$ In a review 2 years later, I invented the word "purinergic," ATP being a purine nucleotide, and came up with the purinergic hypothesis (Fig. 2). ${ }^{18} \mathrm{Un}$ fortunately, this concept met with almost universal opposition during the following 20 years. This was perhaps not surprising, because ATP was well established as an intracellular energy source, and it seemed unlikely that such a ubiquitous molecule would also be involved in extracellular signalling. ${ }^{19,20}$

\section{Purinergic cotransmission}

During a sabbatical leave at UCLA, we showed that ATP was released not only from NANC nerves in the taenia coli but also from sympathetic nerves supplying the smooth muscle. ${ }^{21}$ This was followed by several other papers supporting the concept that ATP might be a cotransmitter with NA from sympathetic nerves, ${ }^{22,23}$ and I published a Commentary in Neuroscience entitled: "Do some nerve cells release more than one transmitter?" which challenged what had been known as Dale's Principle, that one nerve only released one transmitter. ${ }^{24}$ This was later followed by convincing evidence that the excitatory junction potentials recorded in smooth muscle of the vas deferens in response to sympathetic stimulation $^{25,26}$ were due to release of ATP as a cotransmitter with NA. ${ }^{27,28}$ Parasympathetic nerves supplying the urinary bladder were shown to utilize ATP as a cotransmitter with ACh. ${ }^{17,29}$ The cotransmitter concept was also initially resisted, but it is now well established that every nerve, in both the peripheral and central nervous system (CNS), utilises ATP as a cotransmitter (Table 1). ${ }^{30}$

\section{Purinergic receptors}

In 1978, I recognised from hints in the literature and some simple experiments that there were different receptor families for adenosine (called P1 receptors) and for ATP and ADP (called $\mathrm{P} 2$ receptors). ${ }^{31} \mathrm{P} 1$, but not $\mathrm{P} 2$ receptors, were antagonised by methylxanthines. $\mathrm{P} 2$ receptors were later subdivided into $\mathrm{P} 2 \mathrm{X}$ and $\mathrm{P} 2 \mathrm{Y}$ families, based on pharmacology. ${ }^{32}$ However, widespread acceptance of purinergic signalling did not come until the early 1990s, when the receptors to purines and pyrimidines were cloned and characterised. First, four P1 receptor subtypes were identified: $A_{1}$, $A_{2 A}, A_{2 B}$ and $A_{3} \cdot{ }^{33,34}$ In 1993, we cloned a $G$ protein-coupled ATP receptor, which we named $\mathrm{P}_{2} \mathrm{Y}_{1},{ }^{35}$ at about the same time as David Julius and his colleagues in San Francisco cloned a $\mathrm{P} 2 \mathrm{Y}_{2}$ receptor. ${ }^{36}$ The first two $\mathrm{P} 2 \mathrm{X}$ ion channel receptors were cloned and characterised the following year. ${ }^{37,38}$ Later, a formal division into P2X ionotropic and P2Y metabotropic receptor families was proposed. ${ }^{39}$

A major conceptual advance was made when the crystal structure of P2X4 receptors was presented (Fig. 3), ${ }^{40}$ thereby enabling medicinal chemists to start development of selective P2X receptor agonists and antagonists for therapeutic purposes. Cloning of P2 receptors led to studies of immunohistochemical localization of purinoceptors, and this showed that most non-neuronal cells, as well as neurones, expressed multiple P2 receptors. ${ }^{41}$ More recent studies have shown that $\mathrm{P} 2 \mathrm{X}$ purinoceptors are expressed in primitive animals, such as amoeba and Schistosoma, that have comparable molecular structures to those identified in mammals, indicating that ATP was likely one of the earliest extracellular messengers. ${ }^{42}$ 


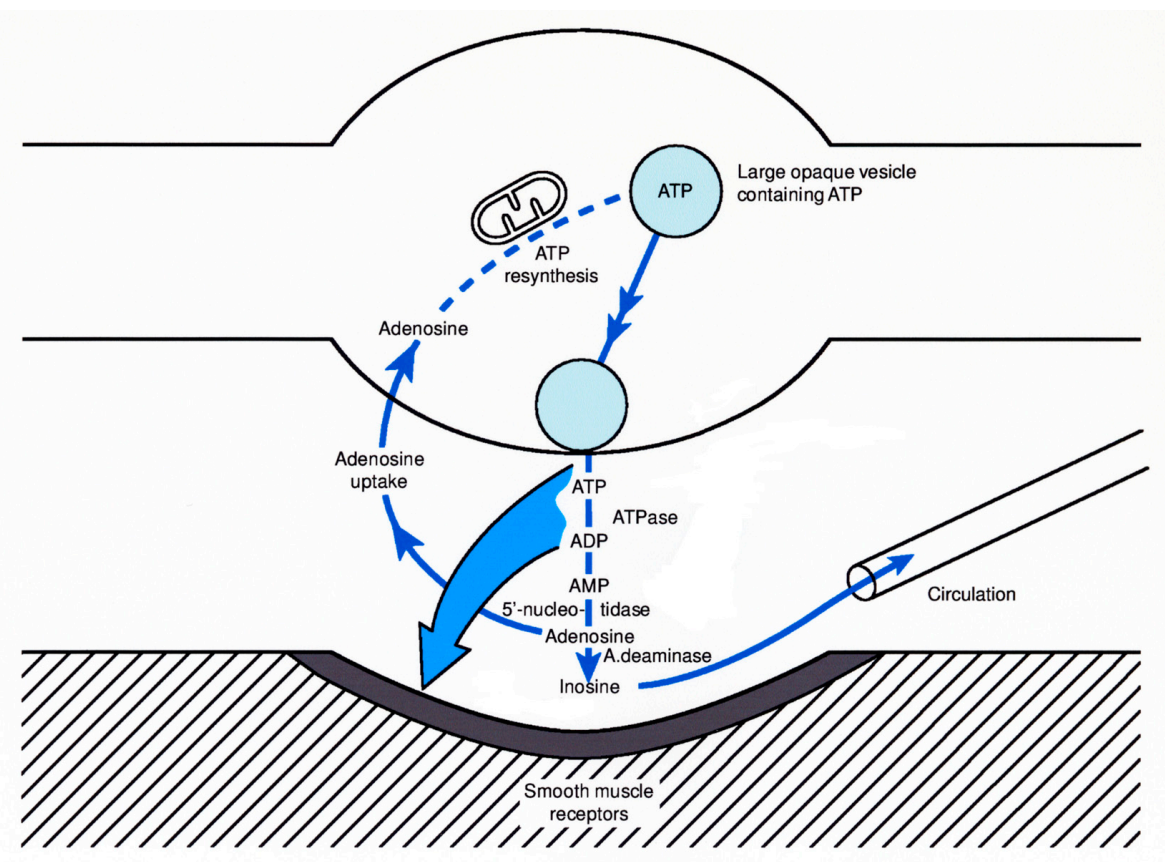

Fig. 2 Purinergic neuromuscular transmission depicting the synthesis, storage, release and inactivation of ATP. ATP stored in vesicles in nerve varicosities is released by exocytosis to act on postjunctional receptors for ATP on smooth muscle. ATP is broken down extracellularly by ATPases and 5'-nucleotidase to adenosine, which is taken up by varicosities to be resynthesised and reincorporated into vesicles. Adenosine is broken down further by adenosine deaminase (A.deaminase) to inosine and hypoxanthine and removed by the circulation. (Reproduced from Burnstock ${ }^{18}$ with permission from the American Society for Pharmacology and Experimental Therapeutics.)

Table 1 Summary of cotransmitters in the peripheral and central nervous systems (Modified from Abbracchio et al ${ }^{99}$ with permission from Elsevier)

\begin{tabular}{lll}
\hline \hline & Cotransmitters & References \\
\hline Peripheral nervous system & ATP + NA + NPY & 28,100 \\
Sympathetic nerves & ATP + ACh +VIP & 101 \\
Parasympathetic nerves & ATP + CGRP + SP & 102 \\
Sensory-motor & ATP +NO + VIP & 103,104 \\
NANC enteric nerves & ATP + ACh & 105,106 \\
Motor nerves (in early development) & & 107 \\
Central nervous system & ATP + ACh & 108,109 \\
Cortex, caudate nucleus & ATP + NA & 110 \\
Hypothalamus, locus coeruleus & ATP + GABA & 111 \\
Hypothalamus, dorsal horn, retina & ATP + DA & 112,113 \\
Mesolimbic system & ATP + glutamate & \\
Hippocampus, dorsal horn & & \\
\hline
\end{tabular}

NPY, neuropeptide Y; ACh, acetylcholine; VIP, vasoactive intestinal peptide; CGRP, calcitonin gene-related peptide; SP, substance P; NO, nitric oxide; GABA, $\gamma$-aminobutyric acid; DA, dopamine

\section{Purinergic synaptic transmission}

Purinergic synaptic neurotransmission was reported between neurones in ganglia ${ }^{43,44}$ and in the brain. ${ }^{45}$ This was a conceptual step, which was particularly influential to neuroscientists interested in the CNS.

\section{Short- and long-term (trophic) purinergic signalling}

In addition to short-term purinergic signalling in neurotransmission, neuromodulation, secretion and platelet aggregation, it is now recognised that long-term (trophic) purinergic signalling is involved in cell proliferation, dif- 


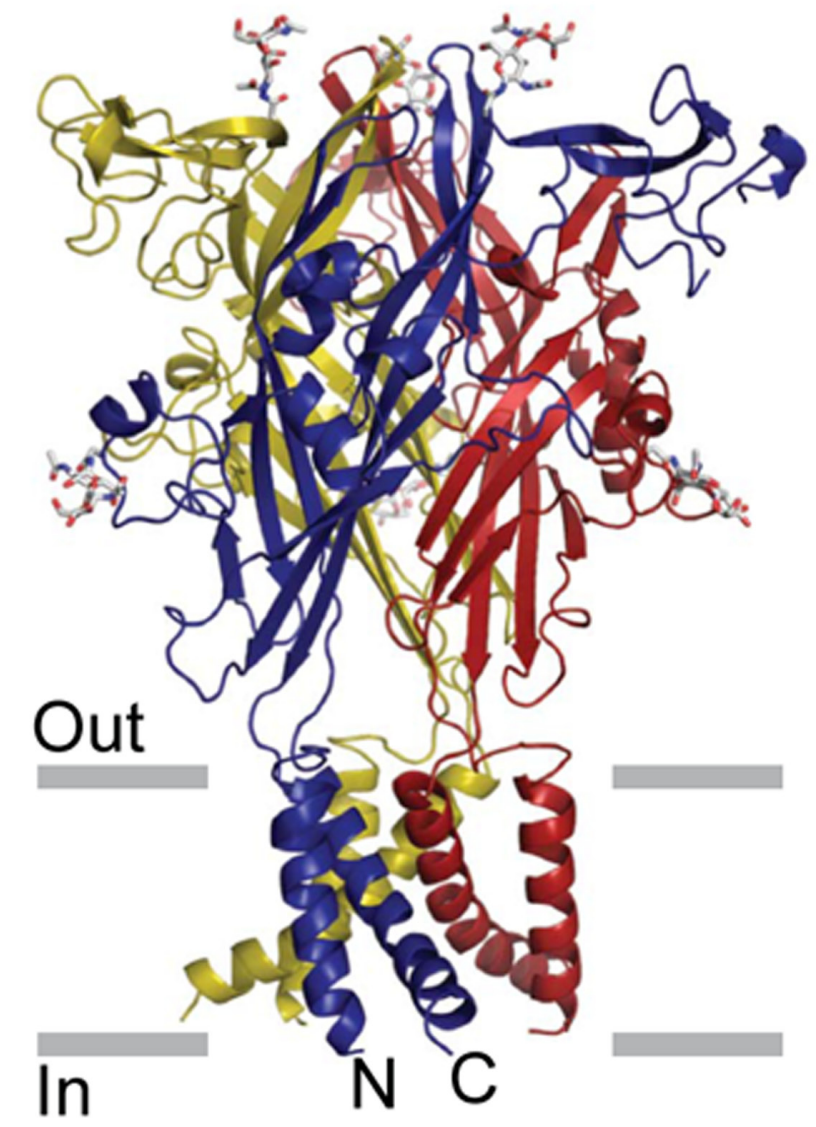

Fig. 3 The architecture of the P2X4 receptor. Stereoview of the homotrimeric $\Delta \mathrm{zfP} 2 \mathrm{X} 4$ structure viewed parallel to the membrane. Each subunit is depicted in a different colour. $\mathrm{N}$-acetylglucosamine and glycosylated asparagine residues are shown in stick representation. The grey bars suggest the boundaries of the outer (Out) and inner (In) leaflets of the membrane bilayer. (Reproduced from Kawate et $\mathrm{al}^{40}$ with permission from the Nature Publishing Group.)

ferentiation and death during development and regeneration, ${ }^{46}$ for example in vascular ${ }^{47}$ and bone ${ }^{48}$ remodelling, and in cancer. ${ }^{49}$ There is evidence that ATP acts synergistically with growth factors to produce trophic signalling, for example, during neurite extension following transplantation of the myenteric plexus into the brain ${ }^{50}$ and in stem cell differentiation. ${ }^{51,52}$

\section{ATP release and breakdown}

It is now recognised that ATP is released, without causing any damage, from many cell types, although for many years it was assumed that the main source of ATP acting on purinoceptors was damaged or dying cells. Endothelial and urothelial cells, astrocytes, macrophages, osteoblasts, odontoblasts and many other cell types have been reported to release ATP in response to gentle mechani- cal disturbance, hypoxia and some agents. ${ }^{53,54}$ Purinergic mechanosensory transduction occurs in a variety of physiological and pathophysiological events, including visceral pain. ${ }^{55,56}$ The mechanism of ATP transport from cells appears to be a combination of connexin and pannexin-1 hemichannels and vesicular exocytosis. Much is now known about the ectoenzymes involved in the breakdown of released ATP into ADP, AMP, adenosine, inosine and hypoxanthine. ${ }^{57,58}$ The enzymes involved include ectonucleoside triphosphate diphosphohydrolases, ecto-nucleotide pyrophosphatase/phosphodiesterases, alkaline phosphatases, 5'-nucleotidase and monoamine oxidase.

\section{Pathophysiology and Therapeutic Potential}

\section{Bladder disorders}

In contrast to laboratory animals, in which the purinergic component of parasympathetic cotransmission supplying the bladder is about $50 \%$, in healthy human bladder it is only about $2 \%$, even though receptors for ATP are expressed by the smooth muscle. However, in pathological conditions such as interstitial cystitis, outflow obstruction and neurogenic bladder, the purinergic component increases to up to $40 \%$ and is therefore a target for therapeutic treatment. ${ }^{3}$ Botulinum neurotoxin type A is widely used to treat bladder incontinence and acts by inhibiting the release of ATP and ACh from both parasympathetic nerves and urothelial cells. ${ }^{59,60}$

\section{Cardiovascular disorders}

ADP acting via $\mathrm{P} 2 \mathrm{Y}_{1}$ and $\mathrm{P} 2 \mathrm{Y}_{12}$ receptors mediates platelet aggregation, and so $\mathrm{P} 2 \mathrm{Y}_{12}$ receptor antagonists clopidogrel and related compounds are widely used for the treatment of thrombosis and stroke. ${ }^{61,62}$

There are reports that in spontaneously hypertensive rats there is a significantly greater cotransmitter role for ATP in sympathetic nerves supplying blood vessels. ${ }^{4}$ Long-term purinergic control of proliferation of smooth muscle and endothelial cells via P1 and P2Y receptors during vascular remodelling in restenosis following angioplasty and in atherosclerosis has been reported, and therapeutic possibilities are being explored. ${ }^{47}$

There is increased expression of $\mathrm{P} 2 \mathrm{X} 1$ and $\mathrm{P} 2 \mathrm{Y}_{2}$ receptors in the hearts of rats with congestive heart failure. ${ }^{63}$

\section{Diabetes}

$\alpha$-Cells in pancreatic islets express $\mathrm{P} 2 \mathrm{X} 7$ receptors. In streptozotocin-induced diabetes, these $\mathrm{P} 2 \mathrm{X} 7$ receptorexpressing cells replace the space no longer occupied by insulin-containing $\beta$-cells. ${ }^{64}$ Purinergic compounds are being explored for the treatment of diabetes. ${ }^{65}$ 


\section{Osteoporosis}

The involvement of purinergic signalling in bone development and regeneration has been reported, and therapeutic approaches are being explored for osteoporosis, in particular treatment with $\mathrm{P} 2 \mathrm{X} 7$ receptor antagonists. ${ }^{47,66}$

\section{Kidney failure}

There is rich expression of purinoceptor subtypes in the kidney, both in the glomerulus and tubules. Increased expression of $\mathrm{P} 2 \mathrm{X} 7$ receptors in diabetes, hypertension, polycystic kidney disease and glomerulonephritis is opening up novel purinergic possibilities for the treatment of kidney failure. ${ }^{67-69}$

\section{Erectile dysfunction and in vitro fertilization (IVF)}

Abnormalities in purinergic signalling may be involved in the pathophysiology of erectile dysfunction associated with diabetes and prostate enlargement and might be a target for therapy. ${ }^{70-72}$

Treatment of sperm with extracellular ATP improves the in vitro fertility rate for IVF. ${ }^{73,74}$

\section{Gut disorders}

A variety of different activities in the gut involve purinergic signalling, including peristalsis, synaptic transmission in both myenteric and submucous plexuses, vascular tone, mucosal secretion and pain. ${ }^{75}$ Exploratory studies for purinoceptors as therapeutic targets for gut disorders are in progress, ${ }^{76}$ including $\mathrm{P} 2 \mathrm{X} 3$ receptor antagonists for inflammatory bowel disease. ${ }^{77}$

\section{Cystic fibrosis}

A long-lasting $\mathrm{P} 2 \mathrm{Y}_{2}$ receptor agonist has been developed and has been in clinical trials for the treatment of cystic fibrosis. It has been accepted on the Japanese drug market for the treatment of dry eye. ${ }^{78}$

\section{Hyperventilation}

Cells of the neuroendocrine bodies, which line the lungs at intervals in the epithelium, release ATP in response to distension, which then acts via $\mathrm{P} 2 \mathrm{X} 3$ receptors to activate vagal sensory fibres originating in the nodose ganglion. ${ }^{79,80}$ This appears to be a mechanism underlying reflex responses to hyperventilation and noxious gases.

\section{HIV/AIDS}

Recent papers have implicated purinergic signalling in HIV/AIDS and may offer novel therapeutic approaches. ${ }^{81-83}$

\section{Pain}

The involvement of purinergic signalling in the initiation of pain was proposed in an article in the Lancet in $1996 .{ }^{84}$ It was proposed that $\mathrm{P} 2 \mathrm{X} 3$ receptors, expressed on nociceptive nerve endings, ${ }^{85}$ were stimulated by ATP released as a cotransmitter from sympathetic nerves during causalgia and reflex sympathetic dystrophy. It was also suggested that ATP was released from endothelial cells in the microvasculature supplying heart, skeletal muscle and cerebral vessels during angina, ischemia and migraine and from tumour cells during cancer pain. Later, purinergic mechanosensory transduction was identified (Fig. 4) $)^{55}$ and its involvement in the initiation of visceral pain proposed. ${ }^{86,87} \mathrm{Kazu}$ Inoue and colleagues showed that there was increased expression of P2X4 receptors on microglia in neuropathic pain, and this pain was reduced by antagonists to the $\mathrm{P} 2 \mathrm{X} 4$ receptor and in $\mathrm{P} 2 \mathrm{X} 4$ receptor knockout mice ${ }^{88,89}$ Later, antagonists to $\mathrm{P} 2 \mathrm{X} 7$ and $\mathrm{P} 2 \mathrm{Y}$ receptors expressed on microglia were also shown to reduce neuropathic pain. ${ }^{86} \mathrm{P} 2 \mathrm{X} 3$ and $\mathrm{P} 2 \mathrm{X} 7$ receptors are being targeted for the treatment of arthritis. ${ }^{90,91}$

\section{Disorders of the CNS}

Investigations of the roles of purinergic signalling have been reported in disorders of the CNS, including injury due to accidents, surgery, stroke and ischemia, neurodegenerative diseases (such as Alzheimer's, Parkinson's and Huntington's diseases), multiple sclerosis, epilepsy and neuropsychiatric disorders (including schizophrenia, depression and anxiety). ${ }^{56,92,93}$

\section{Cancer}

It was recognised early that ATP was effective against cancer. ${ }^{94}$ More recent studies have shown that $\mathrm{P}_{2} \mathrm{Y}_{1}$ and $\mathrm{P} 2 \mathrm{Y}_{2}$ receptors mediate proliferation in most tumours, that $\mathrm{P} 2 \mathrm{X} 5$ receptors mediate differentiation and therefore are anti-proliferative, and that $\mathrm{P} 2 \mathrm{X} 7$ receptors lead to apoptotic death of tumour cells (Fig. 5). ${ }^{5,49}$ The therapeutic potential of $\mathrm{P} 2 \mathrm{Y}_{1}$ and $\mathrm{P} 2 \mathrm{Y}_{2}$ receptor antagonists and $\mathrm{P} 2 \mathrm{X} 5$ and $\mathrm{P} 2 \mathrm{X} 7$ receptor agonists is being explored. 


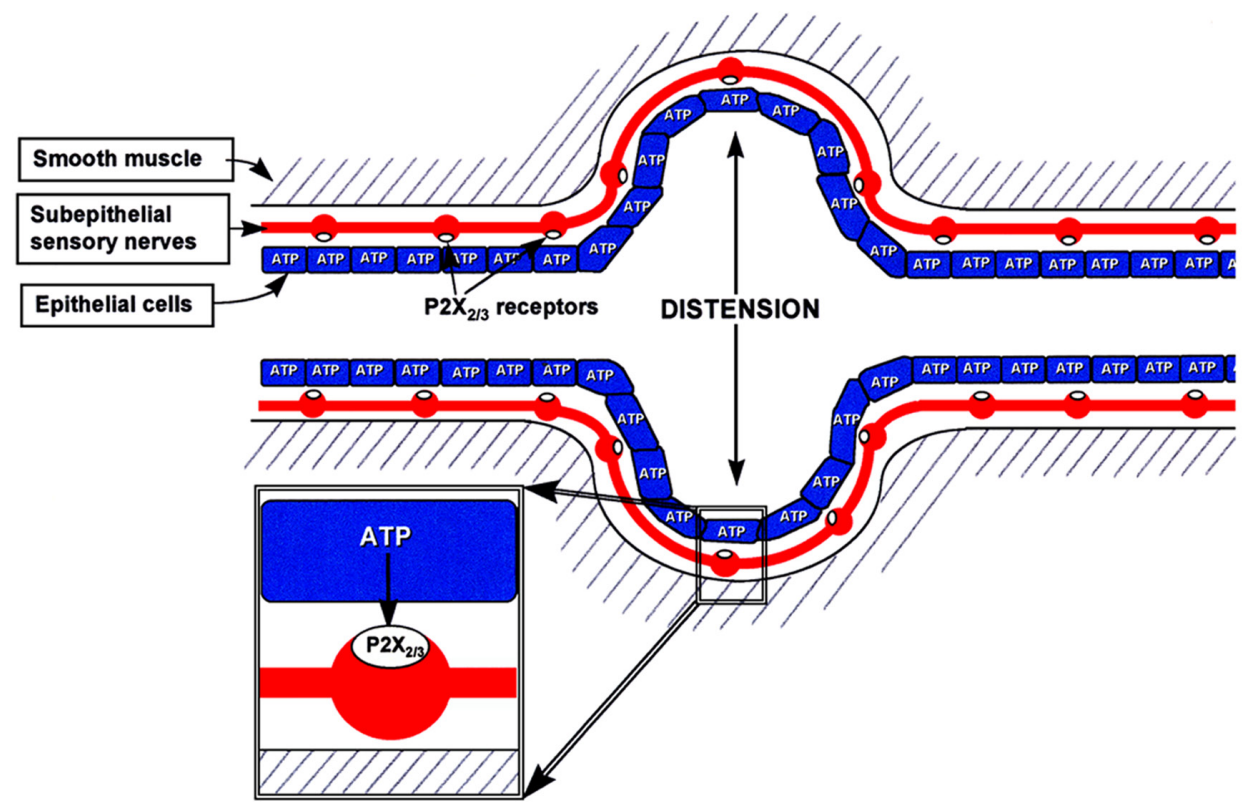

Fig. 4 Schematic hypothesis for purinergic mechanosensory transduction in tubes (e.g., ureter, vagina, salivary and bile ducts, gut) and sacs (e.g., urinary and gall bladders and lung). It is proposed that distension leads to release of ATP from epithelium lining the tube or sac, which then acts on $\mathrm{P} 2 \mathrm{X} 3$ and/or P2X2/3 receptors on subepithelial sensory nerves to convey sensory/nociceptive information to the CNS. (Reproduced from Burnstock ${ }^{55}$ with permission from Blackwell Publishing.)

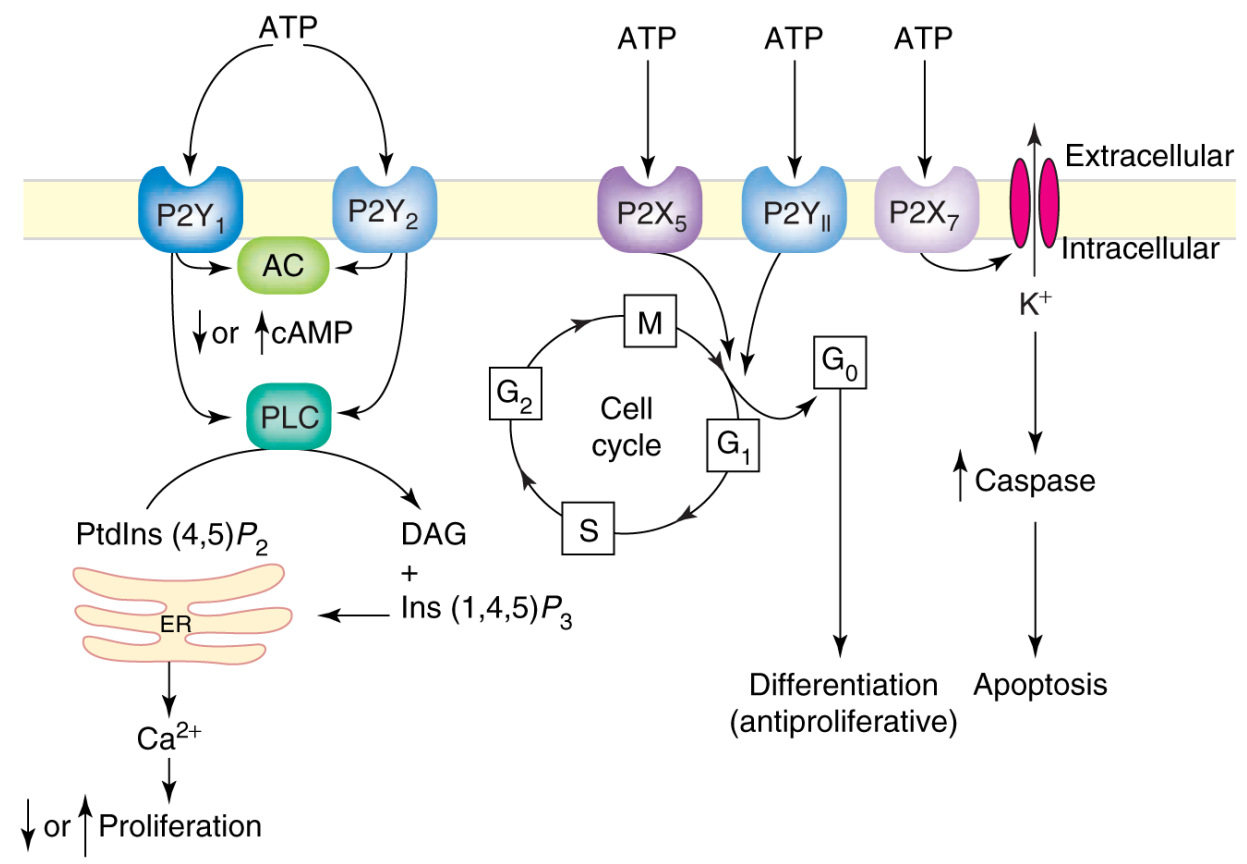

Fig. 5 Schematic of the different mechanisms by which P2 receptor subtypes might alter cancer cell function.

$\mathrm{P} 2 \mathrm{Y}_{1}$ and $\mathrm{P} 2 \mathrm{Y}_{2}$ receptors could affect the rate of cell proliferation through altering the intracellular levels of cAMP by modulating adenylyl cyclase (AC) or by increasing intracellular calcium levels through the phospholipase C (PLC) pathway. P2X5 and P2Y 11 receptor activation might switch the cell cycle from proliferation into a state of differentiation. The P2X7 receptor activates the apoptotic caspase enzyme system. PtdIns $(4,5) P_{2}$, phosphatidylinositol 4,5-bisphosphate; DAG, diacylglycerol; ER, endoplasmic reticulum. (Reproduced from White and Burnstock ${ }^{49}$ with permission from Elsevier.) 


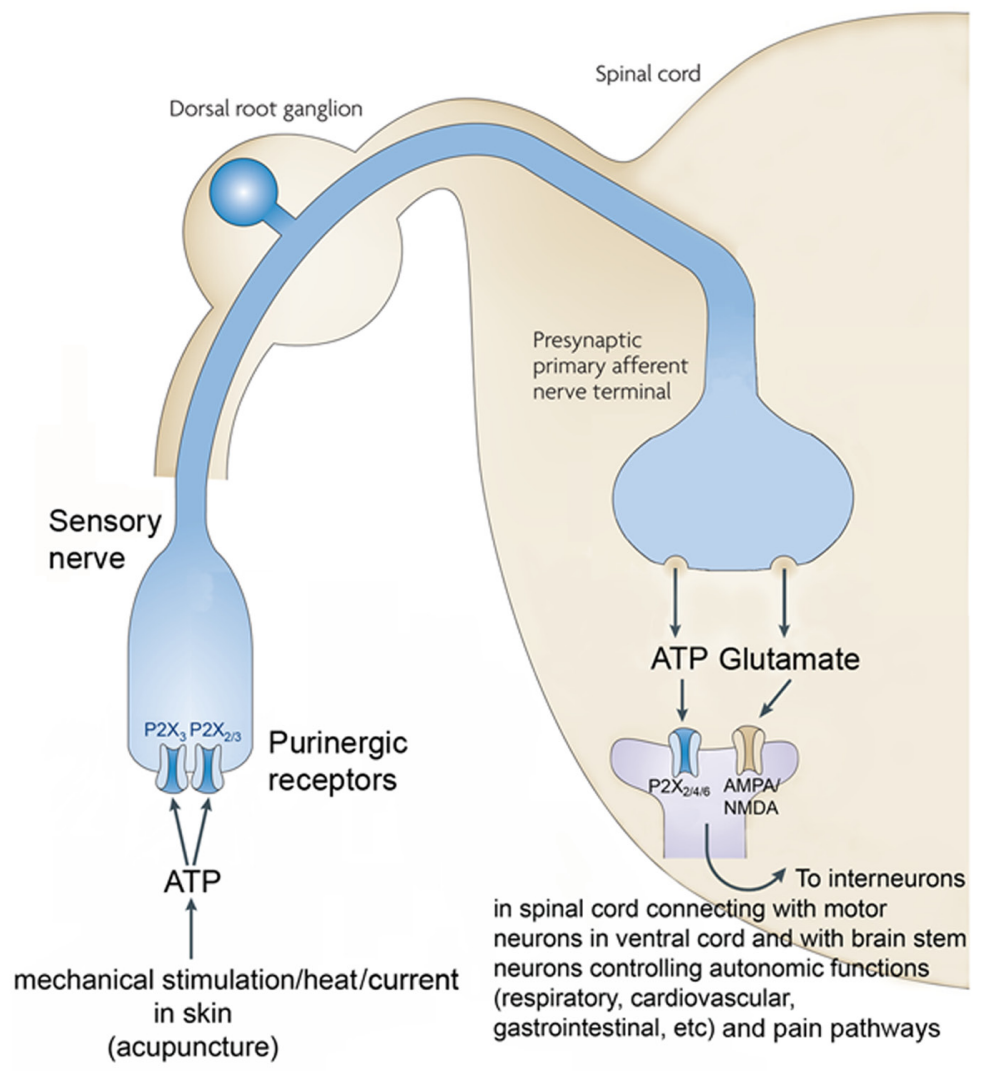

Fig. 6 Schematic hypothesis of purinergic signalling in acupuncture.

AMPA, 2-amino-3-(3-hydroxy-5-methyl-isoxazol-4-yl)propanoic acid; NMDA, $N$-methyl-D-aspartate. (Reproduced from Burnstock ${ }^{95}$ with permission from Elsevier.)

\section{Diseases of the special senses}

Purinergic signalling is much involved in the physiology of the eye, ear, nasal organs and tongue. Consequently, purinergic therapeutic strategies are being developed for glaucoma, retinal detachment, diabetic retinopathy, Ménière's disease, tinnitus, sensorineural deafness, noxious odour damage and taste defects. ${ }^{1}$

\section{Acupuncture}

Acupuncture has been used over many years to treat a wide variety of diseases and to alleviate pain. The traditional Chinese view is that manipulation of the flow of meridian energy (qi) is the underlying mechanism for acupuncture. However, it seems more likely that the nervous system is involved. It has been proposed that purinergic signalling is a major factor in the physiological mechanism responsible for the effects of acupuncture. ${ }^{95}$ It is suggested that mechanical stimulation caused by twisting needles in the skin and tongue, heat, electri- cal currents or laser treatment leads to release of ATP from keratinocytes and mast cells that accumulate at acupuncture sites. ATP then initiates activity via P2X3 receptors on sensory nerves supplying the skin that relay messages through interneurones to the brain stem where they modulate the activity of motor neurones that control autonomic function (Fig. 6). Sensory messages will also modulate the pain pathways leading to the conscious pain centres in the cortex.

\section{Concluding Comments}

The clinical manipulation of purinergic signalling is in its infancy. Therapeutic strategies to deal with pathological disorders include the design of selective $\mathrm{P} 1$ and $\mathrm{P} 2$ receptor subtype agonists and antagonists, as well as of inhibitors of extracellular ATP breakdown and of ATP transport enhancers and inhibitors. Medicinal chemists are developing small-molecule purinergic drugs that are orally bioavailable and stable in vivo. ${ }^{3,6,96,97}$ There has been a remarkable growth in the number of papers published about purinergic signalling via ATP since 1972 (Fig. 7). 


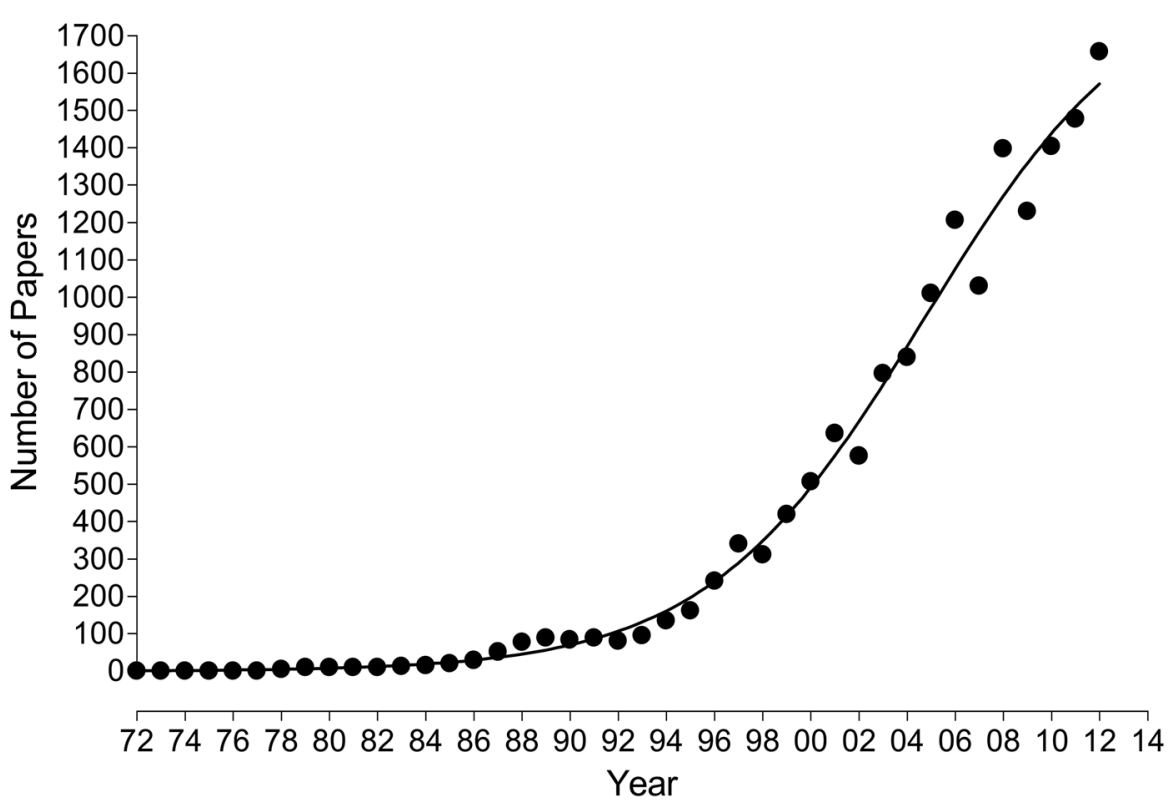

Fig. 7 Graph showing the number of papers published on P2 purinergic signalling between 1972 and the end of 2012. (Reproduced and updated from Burnstock ${ }^{20}$ with permission from John Wiley \& Sons.)

\section{References}

1. Burnstock G: Pathophysiology and therapeutic potential of purinergic signaling. Pharmacol Rev 2006; 58: 58-86. [Medline] [CrossRef]

2. Burnstock G: Purinergic receptors and pain. Curr Pharm Des 2009; 15: 1717-1735. [Medline] [CrossRef]

3. Burnstock G: Therapeutic potential of purinergic signalling for diseases of the urinary tract. BJU Int 2011; 107: 192-204. [Medline] [CrossRef]

4. Erlinge D, Burnstock G: P2 receptors in cardiovascular physiology and disease. Purinergic Signal 2008; 4: 1-20. [Medline] [CrossRef]

5. Shabbir M, Burnstock G: Purinergic receptor-mediated effects of adenosine 5 '-triphosphate in urological malignant diseases. Int J Urol 2009; 16: 143-150. [Medline] [CrossRef]

6. Burnstock G, Kennedy C: P2X receptors in health and disease; in: Jacobson KA, Linden J, eds, Purine and Pyrimidine Receptor Pharmacology. Burlington, Academic Press, 2011; 333-372.

7. Burnstock G, Novak I: Purinergic signalling in the pancreas in health and disease. J Endocrinol 2012; 213: 123-141. [Medline] [CrossRef]

8. Burnstock G, Knight GE, Greig AV: Purinergic signalling in healthy and diseased skin. J Invest Dermatol 2012; 132: 526-546. [Medline] [CrossRef]

9. Burnstock G, Straub RW: A method for studying the effects of ions and drugs on the resting and action potentials in smooth muscle with external electrodes. J Physiol 1958; 140: 156-167. [Medline]

10. Burnstock G: The effects of acetylcholine on membrane potential, spike frequency, conduction velocity and excitability in the taenia coli of the guinea-pig. J Physiol 1958; 143: 165-182. [Medline]

11. Burnstock G: The action of adrenaline on excitability and membrane potential in the taenia coli of the guinea-pig and the effect of DNP on this action and on the action of acetylcholine. J Physiol 1958; 143: 183-194. [Medline]

12. Burnstock G, Campbell G, Bennett M, Holman ME: Innervation of the guinea-pig taenia coli: are there intrinsic inhibitory nerves which are distinct from sympathetic nerves? Int J Neuropharmacol 1964; 3: 163-166. [Medline] [CrossRef]

13. Burnstock G, Campbell G, Rand MJ: The inhibitory innervation of the taenia of the guinea-pig caecum. J Physiol 1966; 182: 504526. [Medline]

14. Drury AN, Szent-Györgyi A: The physiological activity of adenine compounds with special reference to their action upon the mammalian heart. J Physiol 1929; 68: 213-237. [Medline]

15. Holton P: The liberation of adenosine triphosphate on antidromic stimulation of sensory nerves. J Physiol 1959; 145: 494-504. [Medline]

16. Burnstock G, Campbell G, Satchell D, Smythe A: Evidence that adenosine triphosphate or a related nucleotide is the transmitter substance released by non-adrenergic inhibitory nerves in the gut. Br J Pharmacol 1970; 40: 668-688. [Medline] [CrossRef]

17. Burnstock G, Dumsday B, Smythe A: Atropine resistant excitation of the urinary bladder: the possibility of transmission via nerves releasing a purine nucleotide. Br J Pharmacol 1972; 44: 451-461. [Medline] [CrossRef]

18. Burnstock G: Purinergic nerves. Pharmacol Rev 1972; 24: 509581. [Medline]

19. Burnstock G: Historical review: ATP as a neurotransmitter. Trends Pharmacol Sci 2006; 27: 166-176. [Medline] [CrossRef]

20. Burnstock G: The Gaddum Lecture. Discovery of purinergic signalling, the initial resistance and current explosion of interest. $\mathrm{Br}$ J Pharmacol 2012; 167: 238-255. [Medline] [CrossRef]

21. Su C, Bevan JA, Burnstock G: $\left[{ }^{3} \mathrm{H}\right]$ adenosine triphosphate: release during stimulation of enteric nerves. Science 1971; 173: 336-338. [Medline] [CrossRef]

22. Nakanishi H, Takeda H: The possible role of adenosine triphosphate in chemical transmission between the hypogastric nerve 
terminal and seminal vesicle in the guinea-pig. Jpn J Pharmacol 1973; 23: 479-490. [Medline] [CrossRef]

23. Langer SZ, Pinto JE: Possible involvement of a transmitter different from norepinephrine in residual responses to nerve stimulation of cat nictitating membrane after pretreatment with reserpine. J Pharmacol Exp Ther 1976; 196: 697-713. [Medline]

24. Burnstock G: Do some nerve cells release more than one transmitter? Neuroscience 1976; 1: 239-248. [Medline] [CrossRef]

25. Burnstock G, Holman ME: Autonomic nerve-smooth muscle transmission. Nature 1960; 187: 951-952. [Medline] [CrossRef]

26. Burnstock G, Holman ME: The transmission of excitation from autonomic nerve to smooth muscle. J Physiol 1961; 155: 115-133. [Medline]

27. Sneddon P, Burnstock G: Inhibition of excitatory junction potentials in guinea-pig vas deferens by $\alpha, \beta$-methylene-ATP: further evidence for ATP and noradrenaline as cotransmitters. Eur J Pharmacol 1984; 100: 85-90. [Medline] [CrossRef]

28. Westfall DP, Stitzel RE, Rowe JN: The postjunctional effects and neural release of purine compounds in the guinea-pig vas deferens. Eur J Pharmacol 1978; 50: 27-38. [Medline] [CrossRef]

29. Burnstock G, Cocks T, Crowe R, Kasakov L: Purinergic innervation of the guinea-pig urinary bladder. Br J Pharmacol 1978; 63: 125-138. [Medline] [CrossRef]

30. Burnstock G: Cotransmission; in: Robertson D, Biaggioni I, Burnstock G, Low P, Paton JF, eds, Primer of the Autonomic Nervous System 3rd Edition. Oxford, Academic Press, 2012; 27-34.

31. Burnstock G: A basis for distinguishing two types of purinergic receptor; in: Straub RW, Bolis L, eds, Cell Membrane Receptors for Drugs and Hormones: A Multidisciplinary Approach. New York, Raven Press, 1978; 107-118.

32. Burnstock $G$, Kennedy C: Is there a basis for distinguishing two types of $\mathrm{P}_{2}$-purinoceptor? Gen Pharmacol 1985; 16: 433-440. [Medline] [CrossRef]

33. Daly JW: Adenosine receptors. Adv Cyclic Nucleotide Protein Phosphorylation Res 1985; 19: 29-46. [Medline]

34. Fredholm BB, IJzerman AP, Jacobson KA, Klotz KN, Linden J: International Union of Pharmacology. XXV. Nomenclature and classification of adenosine receptors. Pharmacol Rev 2001; 53: 527-552. [Medline]

35. Webb TE, Simon J, Krishek BJ, Bateson AN, Smart TG, King BF, Burnstock G, Barnard EA: Cloning and functional expression of a brain G-protein-coupled ATP receptor. FEBS Lett 1993; 324: 219-225. [Medline] [CrossRef]

36. Lustig KD, Shiau AK, Brake AJ, Julius D: Expression cloning of an ATP receptor from mouse neuroblastoma cells. Proc Natl Acad Sci USA 1993; 90: 5113-5117. [Medline] [CrossRef]

37. Brake AJ, Wagenbach MJ, Julius D: New structural motif for ligand-gated ion channels defined by an ionotropic ATP receptor. Nature 1994; 371: 519-523. [Medline] [CrossRef]

38. Valera S, Hussy N, Evans RJ, Adani N, North RA, Surprenant A, Buell G: A new class of ligand-gated ion channel defined by $\mathrm{P}_{2 \mathrm{X}}$ receptor for extra-cellular ATP. Nature 1994; 371: 516-519. [Medline] [CrossRef]

39. Abbracchio MP, Burnstock G: Purinoceptors: are there families of $\mathrm{P}_{2 \mathrm{X}}$ and $\mathrm{P}_{2 \mathrm{Y}}$ purinoceptors? Pharmacol Ther 1994; 64: 445475. [Medline] [CrossRef]

40. Kawate T, Michel JC, Birdsong WT, Gouaux E: Crystal structure of the ATP-gated $\mathrm{P} 2 \mathrm{X}_{4}$ ion channel in the closed state. Nature 2009; 460: 592-598. [Medline] [CrossRef]

41. Burnstock G, Knight GE: Cellular distribution and functions of P2 receptor subtypes in different systems. Int Rev Cytol 2004; 240: 31-304. [Medline] [CrossRef]

42. Burnstock G, Verkhratsky A: Evolutionary origins of the purinergic signalling system. Acta Physiol (Oxf) 2009; 195: 415-447. [Medline] [CrossRef]
43. Evans RJ, Derkach V, Surprenant A: ATP mediates fast synaptic transmission in mammalian neurons. Nature 1992; 357: 503-505. [Medline] [CrossRef]

44. Silinsky EM, Gerzanich V, Vanner SM: ATP mediates excitatory synaptic transmission in mammalian neurones. Br J Pharmacol 1992; 106: 762-763. [Medline] [CrossRef]

45. Edwards FA, Gibb AJ, Colquhoun D: ATP receptor-mediated synaptic currents in the central nervous system. Nature 1992; 359: 144-147. [Medline] [CrossRef]

46. Burnstock G, Verkhratsky A: Long-term (trophic) purinergic signalling: purinoceptors control cell proliferation, differentiation and death. Cell Death Dis 2010; 1: e9. [Medline] [CrossRef]

47. Burnstock G: Purinergic signalling and vascular cell proliferation and death. Arterioscler Thromb Vasc Biol 2002; 22: 364-373. [Medline] [CrossRef]

48. Orriss IR, Burnstock G, Arnett TR: Purinergic signalling and bone remodelling. Curr Opin Pharmacol 2010; 10: 322-330. [Medline] [CrossRef]

49. White N, Burnstock G: P2 receptors and cancer. Trends Pharmacol Sci 2006; 27: 211-217. [Medline] [CrossRef]

50. Schäfer KH, Saffrey MJ, Burnstock G: Trophic actions of 2-chloroadenosine and bFGF on cultured myenteric neurones. Neuroreport 1995; 6: 937-941. [Medline] [CrossRef]

51. Burnstock G, Ulrich H: Purinergic signalling in embryonic and stem cell development. Cell Mol Life Sci 2011; 68: 1369-1394. [Medline] [CrossRef]

52. Ulrich H, Abbracchio MP, Burnstock G: Extrinsic purinergic regulation of neural stem/progenitor cells: implications for CNS development and repair. Stem Cell Rev 2012; 8: 755-767. [Medline] [CrossRef]

53. Bodin P, Burnstock G: Purinergic signalling: ATP release. Neurochem Res 2001; 26: 959-969. [Medline] [CrossRef]

54. Lazarowski ER: Vesicular and conductive mechanisms of nucleotide release. Purinergic Signal 2012; 8: 359-373. [Medline] [CrossRef]

55. Burnstock G: Release of vasoactive substances from endothelial cells by shear stress and purinergic mechanosensory transduction. J Anat 1999; 194: 335-342. [Medline] [CrossRef]

56. Burnstock G: Physiology and pathophysiology of purinergic neurotransmission. Physiol Rev 2007; 87: 659-797. [Medline] [CrossRef]

57. Zimmermann H: Nucleotide signaling in nervous system development. Pflugers Arch 2006; 452: 573-588. [Medline] [CrossRef]

58. Yegutkin GG: Nucleotide- and nucleoside-converting ectoenzymes: Important modulators of purinergic signalling cascade. Biochim Biophys Acta 2008; 1783: 673-694. [Medline] [CrossRef]

59. MacKenzie I, Burnstock G, Dolly JO: The effects of purified botulinum neurotoxin type A on cholinergic, adrenergic and nonadrenergic, atropine-resistant autonomic neuromuscular transmission. Neuroscience 1982; 7: 997-1006. [Medline] [CrossRef]

60. Chancellor MB, Fowler CJ, Apostolidis A, de Groat WC, Smith CP, Somogyi GT, Aoki KR: Drug Insight: biological effects of botulinum toxin A in the lower urinary tract. Nat Clin Pract Urol 2008; 5: 319-328. [Medline]

61. Gachet C: Regulation of platelet functions by P2 receptors. Annu Rev Pharmacol Toxicol 2006; 46: 277-300. [Medline] [CrossRef]

62. Ahmad S, Storey RF: Development and clinical use of prasugrel and ticagrelor. Curr Pharm Des 2012; 18: 5240-5260. [Medline] [CrossRef]

63. Hou M, Malmsjö M, Möller S, Pantev E, Bergdahl A, Zhao XH, Sun XY, Hedner T, Edvinsson L, Erlinge D: Increase in cardiac $\mathrm{P}_{2} \mathrm{X}_{1}$ - and $\mathrm{P}_{2} \mathrm{Y}_{2}$-receptor mRNA levels in congestive heart failure. Life Sci 1999; 65: 1195-1206. [Medline] [CrossRef] 
64. Coutinho-Silva R, Parsons M, Robson T, Lincoln J, Burnstock G: $\mathrm{P} 2 \mathrm{X}$ and $\mathrm{P} 2 \mathrm{Y}$ purinoceptor expression in pancreas from streptozotocin-diabetic rats. Mol Cell Endocrinol 2003; 204: 141-154. [Medline] [CrossRef]

65. Burnstock G, Novak I: Purinergic signalling and diabetes. Purinergic Signalling 2013 (Epub ahead of print 3/4/13).

66. Agrawal A, Buckley KA, Bowers K, Furber M, Gallagher JA, Gartland A: The effects of $\mathrm{P} 2 \mathrm{X} 7$ receptor antagonists on the formation and function of human osteoclasts in vitro. Purinergic Signal 2010; 6: 307-315. [Medline] [CrossRef]

67. Vonend O, Turner C, Chan CM, Loesch A, Dell'Anna GC, Srai SK, Burnstock G, Unwin R: Glomerular expression of the ATPsensitive $\mathrm{P}_{2} \mathrm{X}_{7}$ receptor in diabetic and hypertensive rat models. Kidney Int 2004; 66: 157-166. [Medline] [CrossRef]

68. Bailey MA, Shirley DG, King BF, Burnstock G, Unwin RJ: Extracellular nucleotides and renal function. in: Alpern RJ, Herbert SCG, eds, The Kidney: Physiology and Pathophysiology, San Diego, Elsevier, 2007; 425-443.

69. Taylor SR, Turner CM, Elliott JI: P2X $X_{7}$ deficiency attenuates renal injury in experimental glomerulonephritis. J Am Soc Nephrol 2009; 20: 1275-1281. [Medline] [CrossRef]

70. Faria M, Timóteo MA, Lafuente-de-Carvalho M, Correia-de-Sá P: P2 Purinoceptor subtype changes in patients with vasculogenic erectile dysfunction. Purinergic Signal 2010; 6: S115.

71. Hupertan V, Neuzillet Y, Stücker O, Pons C, Leammel E, Lebret T: Effects of nucleotides adenosine monophosphate and adenosine triphosphate in combination with L-arginine on male rabbit corpus cavernosum tissue. Int J Androl 2012; 35: 860-866. [Medline] [CrossRef]

72. Wen J, Xia Y: Adenosine signaling: good or bad in erectile function? Arterioscler Thromb Vasc Biol 2012; 32: 845-850. [Medline] [CrossRef]

73. Rossato M, La Sala GB, Balasini M, Taricco F, Galeazzi C, Ferlin A, Foresta C: Sperm treatment with extracellular ATP increases fertilization rates in in-vitro fertilization for male factor infertility. Hum Reprod 1999; 14: 694-697. [Medline] [CrossRef]

74. Vasudevan K, Sztein JM: Treatment of sperm with extracellular adenosine 5 '-triphosphate improves the in vitro fertility rate of inbred and genetically modified mice with low fertility. Theriogenology 2011; 76: 729-736. [Medline] [CrossRef]

75. Burnstock G: The journey to establish purinergic signalling in the gut. Neurogastroenterol Motil 2008; 20: 8-19. [Medline] [CrossRef]

76. Burnstock G: Commentary. Purinergic receptors as future targets for treatment of functional GI disorders. Gut 2008; 57: 1193-1194. [Medline] [CrossRef]

77. Yiangou Y, Facer P, Baecker PA, Ford AP, Knowles CH, Chan CL, Williams NS, Anand P: ATP-gated ion channel $\mathrm{P}_{2} \mathrm{X}_{3}$ is increased in human inflammatory bowel disease. Neurogastroenterol Motil 2001; 13: 365-369. [Medline] [CrossRef]

78. Yerxa BR: Therapeutic use of nucleotides in respiratory and ophthalmic diseases. Drug Dev Res 2001; 52: 196-201. [CrossRef]

79. Brouns I, Adriaensen D, Burnstock G, Timmermans JP: Intraepithelial vagal sensory nerve terminals in rat pulmonary neuroepithelial bodies express $\mathrm{P}_{2} \mathrm{X}_{3}$ receptors. Am J Respir Cell Mol Biol 2000; 23: 52-61. [Medline] [CrossRef]

80. Brouns I, Van Genechten J, Burnstock G, Timmermans JP, Adriaensen D: Ontogenesis of $\mathrm{P} 2 \mathrm{X}_{3}$ receptor-expressing nerve fibres in the rat lung, with special reference to neuroepithelial bodies. Biomed Res 2003; 14: 80-86.

81. Séror C, Melki MT, Subra F, Raza SQ, Bras M, Saïdi H, Nardacci R, Voisin L, Paoletti A, Law F, Martins I, Amendola A, AbdulSater AA, Ciccosanti F, Delelis O, Niedergang F, Thierry S, SaidSadier N, Lamaze C, Métivier D, Estaquier J, Fimia GM, Falasca L, Casetti R, Modjtahedi N, Kanellopoulos J, Mouscadet JF, Ojcius DM, Piacentini M, Gougeon ML, Kroemer G, Perfettini JL: Extracellular ATP acts on P2Y2 purinergic receptors to facilitate
HIV-1 infection. J Exp Med 2011; 208: 1823-1834. [Medline] [CrossRef]

82. Wagner MC: The therapeutic potential of adenosine triphosphate as an immune modulator in the treatment of HIV/AIDS: a combination approach with HAART. Curr HIV Res 2011; 9: 209-222. [Medline] [CrossRef]

83. Narayanan A, Sampey G, Van Duyne R, Guendel I, Kehn-Hall K, Roman J, Currer R, Galons H, Oumata N, Joseph B, Meijer L, Caputi M, Nekhai S, Kashanchi F: Use of ATP analogs to inhibit HIV-1 transcription. Virology 2012; 432: 219-231. [Medline] [CrossRef]

84. Burnstock G: A unifying purinergic hypothesis for the initiation of pain. Lancet 1996; 347: 1604-1605. [Medline] [CrossRef]

85. Chen CC, Akopian AN, Sivilotti L, Colquhoun D, Burnstock G, Wood JN: A P2X purinoceptor expressed by a subset of sensory neurons. Nature 1995; 377: 428-431. [Medline] [CrossRef]

86. Burnstock G: Purinergic mechanosensory transduction and visceral pain. Mol Pain 2009; 5: 69. [Medline] [CrossRef]

87. Burnstock G: Targeting the visceral purinergic system for pain control. Curr Opin Pharmacol 2012; 12: 80-86. [Medline] [CrossRef]

88. Tsuda M, Mizokoshi A, Shigemoto-Mogami Y, Koizumi S, Inoue $\mathrm{K}$ : Activation of $\mathrm{p} 38$ mitogen-activated protein kinase in spinal hyperactive microglia contributes to pain hypersensitivity following peripheral nerve injury. Glia 2004; 45: 89-95. [Medline] [CrossRef]

89. Trang T, Salter MW: P2X4 purinoceptor signaling in chronic pain. Purinergic Signal 2012; 8: 621-628. [Medline] [CrossRef]

90. Al-Shukaili A, Al-Kaabi J, Hassan B: A comparative study of interleukin-1 $\beta$ production and $\mathrm{P}^{2} \mathrm{X}_{7}$ expression after ATP stimulation by peripheral blood mononuclear cells isolated from rheumatoid arthritis patients and normal healthy controls. Inflammation 2008; 31: 84-90. [Medline] [CrossRef]

91. Varani K, De Mattei M, Vincenzi F, Tosi A, Targa M, Masieri FF, Pellati A, Massari L, Borea PA: $\mathrm{P} 2 \mathrm{X}_{1}$ and $\mathrm{P} 2 \mathrm{X}_{3}$ purinergic receptors differentially modulate the inflammatory response in human osteoarthritic synovial fibroblasts. Cell Physiol Biochem 2010; 25 : 325-336. [Medline] [CrossRef]

92. Burnstock G: Purinergic signalling and disorders of the central nervous system. Nat Rev Drug Discov 2008; 7: 575-590. [Medline] [CrossRef]

93. Burnstock G, Krügel U, Abbracchio MP, Illes P: Purinergic signalling: from normal behaviour to pathological brain function. Prog Neurobiol 2011; 95: 229-274. [Medline] [CrossRef]

94. Rapaport E: Treatment of human tumor cells with ADP or ATP yields arrest of growth in the S phase of the cell cycle. J Cell Physiol 1983; 114: 279-283. [Medline] [CrossRef]

95. Burnstock G: Acupuncture: a novel hypothesis for the involvement of purinergic signalling. Med Hypotheses 2009; 73: 470472. [Medline] [CrossRef]

96. Baqi Y, Lee SY, Iqbal J, Ripphausen P, Lehr A, Scheiff AB, Zimmermann H, Bajorath J, Müller CE: Development of potent and selective inhibitors of ecto-5'-nucleotidase based on an anthraquinone scaffold. J Med Chem 2010; 53: 2076-2086. [Medline] [CrossRef]

97. Gever JR, Soto R, Henningsen RA, Martin RS, Hackos DH, Panicker S, Rubas W, Oglesby IB, Dillon MP, Milla ME, Burnstock G, Ford AP: AF-353, a novel, potent orally bioavailable P2X3/ $\mathrm{P} 2 \mathrm{X} 2 / 3$ receptor antagonist. Br J Pharmacol 2010; 160: 13871398. [Medline] [CrossRef]

98. Burnstock G: The changing face of autonomic neurotransmission. (The First von Euler Lecture in Physiology). Acta Physiol Scand 1986; 126: 67-91. [Medline] [CrossRef]

99. Abbracchio MP, Burnstock G, Verkhratsky A, Zimmermann H: Purinergic signalling in the nervous system: an overview. Trends Neurosci 2009; 32: 19-29. [Medline] [CrossRef] 
100. Burnstock G: Noradrenaline and ATP as cotransmitters in sympathetic nerves. Neurochem Int 1990; 17: 357-368. [Medline] [CrossRef]

101. Hoyle CH: Purinergic cotransmission: parasympathetic and enteric nerves. Semin Neurosci 1996; 8: 207-215. [CrossRef]

102. Burnstock G: Introduction: Changing face of autonomic and sensory nerves in the circulation. in: Edvinsson L, Uddman R, eds, Vascular Innervation and Receptor mechanisms: New Perspectives, San Diego, Academic Press Inc, 1993; 1-22.

103. Belai A, Burnstock G: Evidence for coexistence of ATP and nitric oxide in non-adrenergic, non-cholinergic (NANC) inhibitory neurones in the rat ileum, colon and anococcygeus muscle. Cell Tissue Res 1994; 278: 197-200. [Medline] [CrossRef]

104. Burnstock G: Purinergic signalling in gut; in. Abbracchio MP, Williams M, eds, Handbook of Experimental Pharmacology, Volume 151/II. Purinergic and Pyrimidinergic Signalling II - Cardiovascular, Respiratory, Immune, Metabolic and Gastrointestinal Tract Function. Handbook of Experimental Pharmacology, Berlin, Springer-Verlag, 2001. vol 151/II, 141-238.

105. Silinsky EM, Hubbard JI: Release of ATP from rat motor nerve terminals. Nature 1973; 243: 404-405. [Medline] [CrossRef]

106. Henning RH: Purinoceptors in neuromuscular transmission. Pharmacol Ther 1997; 74: 115-128. [Medline] [CrossRef]

107. Richardson PJ, Brown SJ: ATP release from affinity-purified rat cholinergic nerve terminals. J Neurochem 1987; 48: 622-630. [Medline] [CrossRef]
108. Sperlágh B, Sershen H, Lajtha A, Vizi ES: Co-release of endogenous ATP and $\left[{ }^{3} \mathrm{H}\right]$ noradrenaline from rat hypothalamic slices: origin and modulation by $\alpha_{2}$-adrenoceptors. Neuroscience 1998; 82: 511-520. [Medline] [CrossRef]

109. Poelchen W, Sieler D, Wirkner K, Illes P: Co-transmitter function of ATP in central catecholaminergic neurons of the rat. Neuroscience 2001; 102: 593-602. [Medline] [CrossRef]

110. Jo YH, Role LW: Cholinergic modulation of purinergic and GABAergic co-transmission at in vitro hypothalamic synapses. J Neurophysiol 2002; 88: 2501-2508. [Medline] [CrossRef]

111. Krügel U, Schraft T, Kittner H, Kiess W, Illes P: Basal and feeding-evoked dopamine release in the rat nucleus accumbens is depressed by leptin. Eur J Pharmacol 2003; 482: 185-187. [Medline] [CrossRef]

112. Mori M, Heuss C, Gahwiler BH, Gerber U: Fast synaptic transmission mediated by $\mathrm{P} 2 \mathrm{X}$ receptors in CA3 pyramidal cells of rat hippocampal slice cultures. J Physiol 2001; 535: 115-123. [Medline] [CrossRef]

113. Fujii S, Sasaki H, Mikoshiba K, Kuroda Y, Yamazaki Y, Mostafa TA, Kato H: A chemical LTP induced by co-activation of metabotropic and N-methyl-D-aspartate glutamate receptors in hippocampal CA1 neurons. Brain Res 2004; 999: 20-28. [Medline] [CrossRef] 